Chem. Chem. Technol., 2022,

Chemistry

Vol. 16, No. 1, pp. 51-58

\title{
SYNTHESIS AND PROPERTIES OF PHOSPHORUS-CONTAINING PSEUDO-POLY(AMINO ACID)S OF POLYESTER TYPE BASED ON $N$-DERIVATIVES OF GLUTAMINIC ACID
}

\author{
Anna Stasiuk ${ }^{1} \bowtie$, Nataliia Fihurka1, Vasyl Vlizlo ${ }^{2}$, Sofiia Prychak ${ }^{1}$, \\ Dmytro Ostapiv ${ }^{3}$, Serhii Varvarenko ${ }^{1}$, Volodymyr Samaryk ${ }^{1}$
}

https://doi.org/10.23939/chcht16.01.051

\begin{abstract}
Poly(phosphoeter)s (PPE)s are a class of polymers possessing a high chemical functionality and biodegradability. Novel, glutamic acid based poly (phosphoeter)s were synthesized by the Steglich reaction. The developed synthetic approach allows controlling the composition and the structure of PPEs, and therefore their physical and colloidal properties. The studies on solubilization and cytotoxicity in vitro proved the potential of PPEs for drug delivery applications.
\end{abstract}

Keywords: poly(phosphoester)s, pseudo-poly(amino acid)s, glutamic acid, polyethylene glycol, Steglich reaction, drug delivery.

\section{1. Introduction}

Polyesters are considered promising materials for biomedical applications ${ }^{1-3}$ due to a number of properties biodegradability, biocompatibility, availability of raw materials. $^{4-6}$ Their applications include various medical devices - threads, bone fixators, stents, and screws. ${ }^{7-10}$ Researchers pay special attention to preparing polyesterbased dispersed delivery systems for therapeutic agents. ${ }^{11}$ However, polyesters based on dicarboxylic acids and diols $^{12}$ or lactones ${ }^{13}$ do not include functional groups or active centers capable of chemisorption of biological substances and drugs, that significantly limits their use. Therefore, the synthesis of functionalized polyesters still remains an urgent problem. Solving this issue will allow preparing new forms to deliver various biologically active

\footnotetext{
${ }^{1}$ Lviv Polytechnic National University,

12 S. Bandery St., Lviv 79013, Ukraine

${ }^{2}$ Stepan Gzhytskyi National University of Veterinary Medicine and Biotechnologies,

50 Pekarska St., Lviv 79010, Ukraine

${ }^{3}$ Institute of Animal Biology NAAS,

38 V. Stusa St., Lviv 79034, Ukraine

凶anna.v.stasiuk@lpnu.ua

(C) Stasiuk, A.; Fihurka, N.; Vlizlo, V.; Prychak, S.; Ostapiv, D.;

Varvarenko, S.; Samaryk, V., 2022
}

compounds. The introduction of phosphate groups into the polymer chain is particularly promising for this purpose as the pentavalent phosphorus atom is an excellent option for further modification or binding to low molecular weight therapeutic drugs or proteins. ${ }^{14}$

The first attempts to obtain phosphorus-containing polymers were made in the 1950s when scientists tried to mimic the properties of natural phosphorus-containing macromolecules. $^{15}$ To date, synthetic approaches to phosphorus-containing polyesters based on a number of monomers (PEG, lactic acid) have been developing, ${ }^{16-18}$ which largely confirms the relevance of this task. Common methods for the synthesis of polyphosphoesters are polycondensation, transesterification, and ringopening polymerization. ${ }^{19}$ The obtained polymers are biodegradable, biocompatible, ${ }^{20}$ show a low cell adhesion, low toxicity, and stealth effect. ${ }^{21}$. However, despite the prospects of such polymers and a large number of studies in this field, so far none of the polyphosphoesters has reached the stage of clinical trials. ${ }^{22}$ Only a few members of this series are in preclinical studies.

In addition to all the above-mentioned properties, polymers for dispersed drug delivery systems should form stable dispersions in the aqueous medium with the nanometric size of the dispersed phase. ${ }^{23}$ It is desirable that the dispersion stabilization takes place without additional stabilizers. Thus, the polymer should possess surface-active properties. ${ }^{24}$ At the same time, the particles of the dispersed phase should be able to solubilize waterinsoluble organic compounds. Polymer to be used for drug delivery systems should be biodegradable and non-toxic. Moreover, biodegradation products should also be nontoxic. $^{25,26}$

This work reports on a synthetic approach to polyphosphates based on glutamic acid and polyethylene glycols. The described method is an adaptation of the developed by the authors synthetic approach to pseudopolyamino acids (PPAA) of polyester type by the Steglich reaction. 


\section{Experimental}

\subsection{Materials}

Polyoxyethylene/polyoxypropylene

diols (PEG/PPG) were obtained from Sigma-Aldrich and dried by refluxing in benzene with azeotropic removal of water. Phosphorus(V) oxychloride, ethanol, triethylamine, triphenylmethyl chloride, $p$-toluenesulfonic acid were obtained from Sigma-Aldrich and used as received. $N, N^{\prime}$ Dicyclohexylcarbodiimide (DCC) and 4-dimethylaminopyridine (DMAP) were obtained from Alfa Aesar and used as received. The solvents (benzene, ethyl acetate, 1,4-dioxane, methanol, dichloromethane, acetone, hexane) were purified using the procedure described by several authors. ${ }^{27,28}$

\subsection{Research Methods}

\subsubsection{Methods of analysis}

IR spectra were taken on a ThermoScientifis iD5 ATR Nicolet iS5 IR Spectrometer by the technique of attenuated total reflection on a diamond crystal (ATR FTIR). NMR spectra of polymers were taken on JEOL's ECA Series Nuclear Magnetic Resonance (NMR) Spectrometer in automatic conditions of scanning. Analysis of NMR-spectrums was carried out using the tables of chemical shifts characteristics described by Nagornyak et $a l_{.}{ }^{29}$ and Zubyk et al., ${ }^{30}$ as well as the program Shem Bio Draw Ultra 11.0.1. The number of hydroxyl groups was determined by a non-catalytic acetylation and subsequent potentiometric titration. ${ }^{31,32}$ The particles size of the polymeric micelles was determined using Malvern Zetasizer Nano S. The surface tension was determined by the Du Nui method. Solubilization of Sudan III was performed using the procedure described by Demchuk et al. ${ }^{33}$ Survival and activity of sperm oxidative enzymes were performed using the procedure described by several authors. ${ }^{34,35}$

\subsubsection{Methods of synthesis}

Ethyl dichlorophosphate (EDP) was synthesized with the following method. Phosphorus(V) oxychloride $(0.20 \mathrm{~mol})$ was loaded into a reactor equipped with a stirrer and was cooled on a water-ice bath to $273-278 \mathrm{~K}$. Then ethanol $(0.1 \mathrm{~mol})$ was dripped slowly into the reactor. After complete reagent dripping the synthesis continued under stirring at $278-283 \mathrm{~K}$ for $2 \mathrm{~h}$ and at $393 \mathrm{~K}$ for $4 \mathrm{~h}$. Ethyl dichlorophosphate was purified by vacuum distillation. The yield is $75 \%$.

Polyoxyethylene triphenylmethyl ether (PEG-Tr) was synthesized according to the following method. Polyoxyethylene (molecular weight $400 \mathrm{~g} / \mathrm{mol}, 0.7 \mathrm{~mol}$ ), triethylamine $(0.13 \mathrm{~mol})$ and benzene $(200 \mathrm{~mL})$ were loaded into a reactor equipped with a stirrer. Triphenylmethyl chloride $(0.1 \mathrm{~mol})$ in $100 \mathrm{~mL}$ benzene was dripped into the reactor. After $12 \mathrm{~h}$ of stirring at $298 \mathrm{~K}$, the mixture was filtered. Polyoxyethylene triphenylmethyl ester was extracted with ethyl acetate $(150 \mathrm{~mL})$ and washed with water $(3 \times 50 \mathrm{~mL})$. The organic layer was dried over anhydrous sodium sulfate (2-3 g) for $12 \mathrm{~h}$. Polyoxyethylene triphenylmethyl ester was dried under vacuum to a constant weight. The yield is $95 \%$.

Dipolyethylene glycol ethyl phosphate (DEP) was synthesized according to the following method. Polyoxyethylene triphenylmethyl ester (molecular weight $642.28 \mathrm{~g} / \mathrm{mol}, 0.1 \mathrm{~mol})$, triethylamine $(0.105 \mathrm{~mol})$, and 1,4-dioxane $(150 \mathrm{~mL})$ were loaded into a reactor equipped with a stirrer and cooled in a water-ice bath to $273-278 \mathrm{~K}$. Ethyl dichlorophosphate $(0.05 \mathrm{~mol})$ was dripped slowly into the reactor. After complete reagent dripping reaction mixture was stirred at $278-283 \mathrm{~K}$ for $2 \mathrm{~h}$ and $393 \mathrm{~K}$ for $6 \mathrm{~h}$. Then the mixture was filtered and the solvent was evaporated under vacuum. Dipolyoxyethylene ethyl phosphate triphenylmethyl ether (DEP-Tr) was dissolved in $150 \mathrm{~mL}$ methanol. $p$-Toluenesulfonic acid was added in a catalytic amount into a reactor. The mixture was stirred at $298 \mathrm{~K}$ for $2 \mathrm{~h}$. Then $150 \mathrm{~mL}$ water was added into a reactor. After $4 \mathrm{~h}$ of stirring at $298 \mathrm{~K}$, the mixture was filtered. Dipolyethylene glycol ethyl phosphate was dried under vacuum to a constant weight. The yield of DEP-4 is $98.1 \%$.

$N$-derivatives of L-glutamic acid (GluSt, GluL) and pseudo-poly(amino acid)s (PPAA) were synthesized using the procedure described by Varvarenko et al. ${ }^{5}$

Phosphorus-containing polyesters (PPE) were synthesized with the developed method. $N$-derivatives of L-glutamic acid (GluA) (12.5 mmol), phosphoruscontaining diol - dipoly(ethylene glycol) ethyl phosphate (DEP) $(11.3 \mathrm{mmol})$ and dichloromethane were loaded into a reactor. A solution of DCC $(25.4 \mathrm{mmol})$ and catalyst DMAP $(1.6 \mathrm{mmol})$ were dripped into the reaction mixture at the temperature of $280 \mathrm{~K}$. Then the reaction mixture was maintained at $288 \mathrm{~K}$ for $3 \mathrm{~h}$ and at $398 \mathrm{~K}$ for $3 \mathrm{~h}$. Finally, a side product of the reaction dicyclohexylurea (DCU) was filtered off and the reaction mixture was evaporated. The polymer was purified from unreacted monomers, activator, and catalyst by precipitation in acetone from hexane. The product was dried under vacuum to a constant weight.

\section{Results and Discussion}

The Steglich reaction is one of few effective and convenient methods for the synthesis of amino acid esters. In general, the formation of an ester bond occurs due to 
the nucleophilic attack of the alcohol hydroxyl group on the activated carboxyl group of the amino acid. Carboxyl activation occurs by interaction with $N, N^{\prime}$ dicyclohexylcarbodiimide (DCC) according to the Scheme 1. A prerequisite for a successful synthesis is the use of $\mathrm{N}$-derivatives of amino acids, because the free amino group is a stronger nucleophile and will form a peptide bond. A convenient means of controlling the depth of polycondensation is the amount of isolated dicyclohexylurea (DCU) - a side product of the reaction, insoluble in most organic solvents.

We investigated this reaction in a system of $N$ acylated derivatives of glutamic acid ( $N$-stearoyl- (GluSt) and $N$-lauryl-L-glutamic acid (GluL) and polyethylene glycols (PEG) or polypropylene glycols (PPG) of different molecular weight. Several methods for the synthesis of various pseudo-poly(amino acid)s (PPAA) based on the Steglich reaction have been developed.

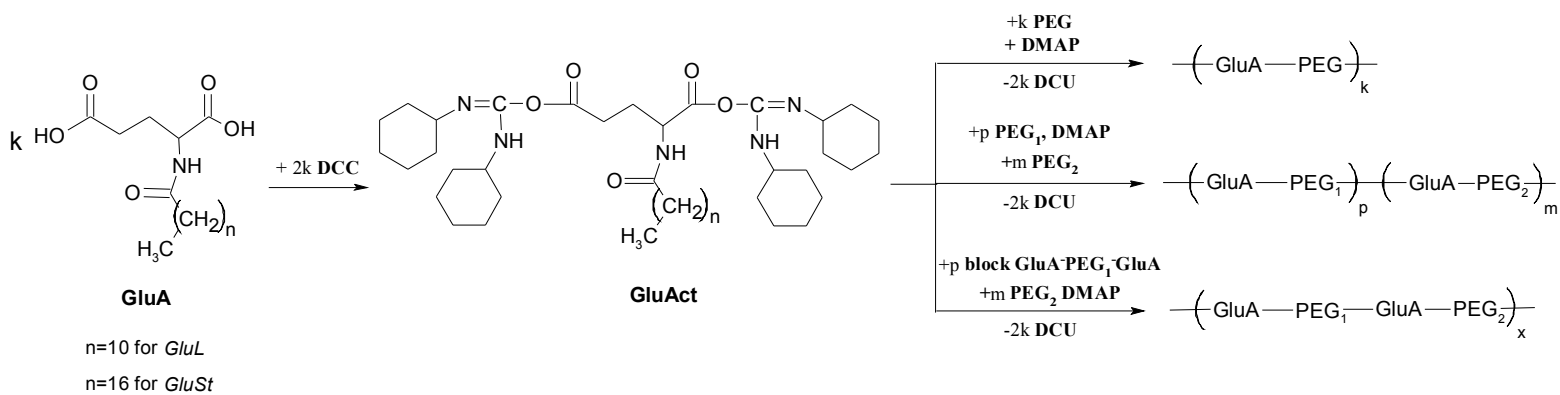

Scheme 1. Polycondensation of $N$-substituted glutamic acid with PEG/PPG diols

First of all, it is the synthesis of alternative PPAA based on $N$-substituted glutamic acid and diol. Modification of the basic technique involves the simultaneous loading of two different diols. This synthetic approach allows simultaneous using diols of different nature (PEG or PPG) and different molecular weights. For a number of obtained copolymers, the equivalent entry of PEG and PPG chains into the copolymer structure was confirmed.

Also, a method for the block copolymers synthesis by the Steglich reaction has been developed. Reactive blocks with terminal carboxyl groups of general structure GluA-PEG-GluA ${ }^{36}$ were used for further polycondensation with a diol differing from that present in the block structure.

Thus, synthetic approaches for a number of PPAA based on $N$-derivatives of glutamic acid and PEG/PPG diols have been developed. These techniques allow regulating the structure and composition of the final copolyester by introducing blocks and monomers of different nature and molecular weight. This, in turn, is an effective way to regulate the hydrophilic-lipophilic balance, and hence the colloidal properties of the obtained polyesters. Thereby, the developed method allows obtaining polyesters capable of forming self-stabilized nanosized dispersions in aqueous and physiological solutions. This fact is crucial for the synthesis of promising polymer drug delivery systems.

As was shown above, a developed synthetic approach to pseudo-poly(amino acid)s of polyester type allows using diols of different nature. Therefore, it seems appropriate to functionalize this class of molecules by introducing a phosphate group into the structure of the diol. For this purpose, polyoxyethylene glycols with ethyl phosphate group were previously synthesized.

The synthesis of dipolyoxyethylene ethyl phosphate (DEP) was carried out in two stages. At the first stage, the dipolyoxyethylene ethyl phosphate triphenylmethyl ether (DEP-Tr) was obtained via a reaction between ethyldichlorophosphate (EDP) and polyoxyethylene triphenylmethyl ether (PEG-Tr) according to Scheme 2. Protection of one of the hydroxyl groups in the polyoxyethylene is necessary to prevent the reaction of both hydroxyl groups, which could lead to polycondensation. IR spectrum of the obtained DEP-Tr is shown in Fig. 1. Table 1 shows the DEP-Tr yield in syntheses with different molecular weights of polyoxyethylene triphenyl ester.

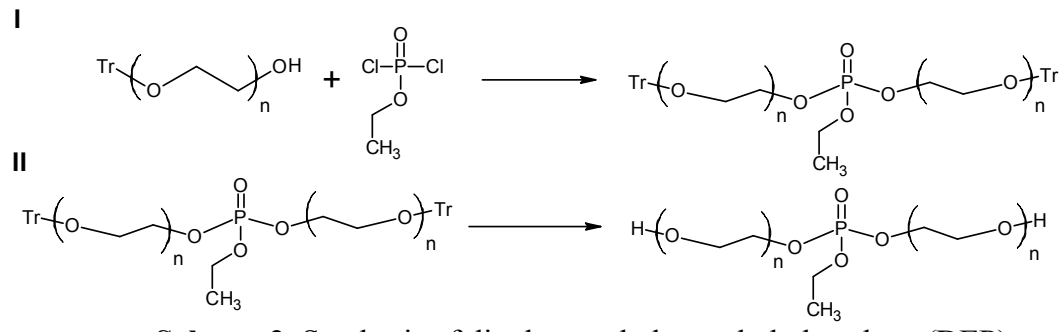

Scheme 2. Synthesis of dipolyoxyethylene ethyl phosphate (DEP) 
Triphenylmethyl protection of hydroxyl groups was removed in an acidic environment. The completeness of deprotection was controlled by the amount of isolated triphenylmethanol that precipitates. Also, it was confirmed by IR spectroscopy due to the disappearance of absorption bands from 590 and $680 \mathrm{~cm}^{-1}$ in the spectrum. The structure of the obtained product was confirmed by ${ }^{1} \mathrm{H}$ and ${ }^{35} \mathrm{P}$ NMR spectroscopy, and the isolated product was characterized by the number of hydroxyl groups (Table 1).

As Table 1 shows, the experimentally determined number of hydroxyl groups satisfactorily corresponds to the calculated one. The yields of DEP-Tr are expectedly high and do not depend on the PEG molecular mass. In contrast, high yields of the DEP product are observed only for polyoxyethylenes with a molecular mass of $600 \mathrm{Da}$ and above. When using PEG with a lower molecular mass, a part of the obtained product is lost during the purification procedure.

The obtained DEP is used in the synthesis of phosphorus-containing polyesters (PPE) by the Steglich reaction according to Scheme 3. In this study, $N$-stearoylglutamic acid was used as it gave high yields of PPAA of the polyester type described above. The ratio between the number of hydroxyl and carboxyl groups 9:10 provides an excess of hydroxyl groups. DCC was used in $10 \%$ excess to carboxyl groups.

Table 1. Comparative characteristics of DEP synthesis

\begin{tabular}{|c|c|c|c|c|c|}
\hline $\begin{array}{c}\text { Synthesis } \\
\text { name }\end{array}$ & $\begin{array}{c}\text { Molecular mass of } \\
\text { PEG-Tr, Da }\end{array}$ & $\begin{array}{c}\text { DEP-Tr } \\
\text { yield, \% }\end{array}$ & $\begin{array}{c}\text { DEP yield, } \\
\%\end{array}$ & $\begin{array}{c}\text { The number of hydroxyl } \\
\text { groups, g eq(OH } \\
\text { groups } / \mathrm{g}(\mathrm{DEP}) \\
\text { exp. }\end{array}$ & $\begin{array}{c}\text { The number of hydroxyl groups, g } \\
\text { eq(OH groups } / \mathrm{g}(\mathrm{DEP}) \\
\text { calc. }\end{array}$ \\
\hline DEP-2 & 442.28 & 98.1 & 61.7 & 0.00396 & 0.00417 \\
\hline DEP-4 & 642.28 & 95.9 & 98.1 & 0.002111 & 0.00226 \\
\hline DEP-6 & 842.28 & 95.0 & 97.0 & 0.00156 & 0.00148 \\
\hline DEP-10 & 1242.28 & 97.2 & 94.0 & 0.000861 & 0.00096 \\
\hline
\end{tabular}

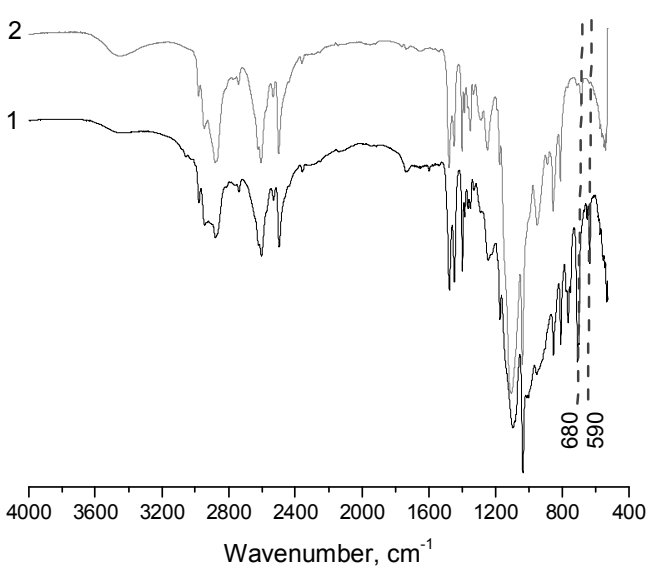

Fig. 1. IR spectra of dipolyoxyethylene ethyl phosphate triphenyl ester (DEP-4-Tr) (1) and dipolyoxyethylene ethyl phosphate (DEP-4) (2)

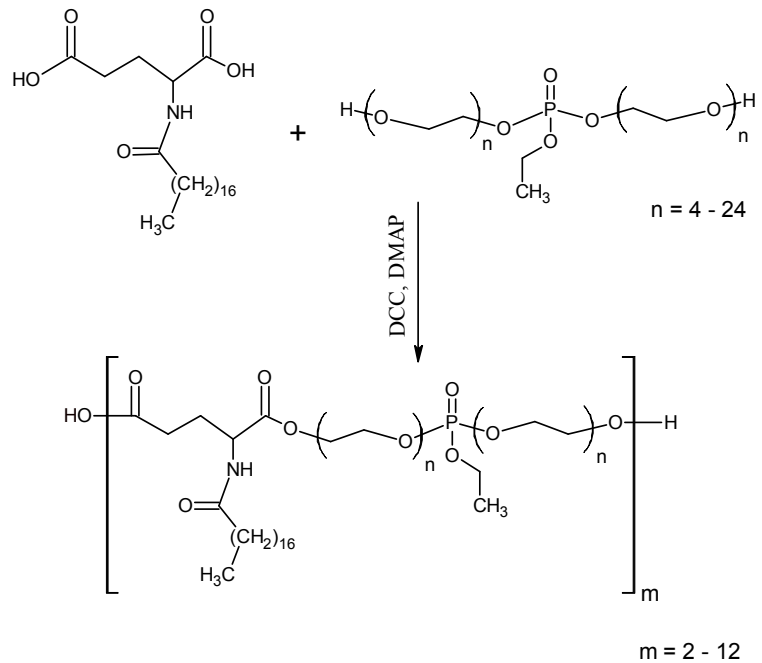

Scheme 3. Synthesis of PPE with an ethylphosphate group

Table 2. The characteristics of obtained PPE

\begin{tabular}{|c|c|c|c|c|c|c|c|c|}
\hline \multirow{2}{*}{$\begin{array}{c}\text { Sample } \\
\text { no }\end{array}$} & Diol & GluSt & Diol & DCC & $\begin{array}{c}\text { DCU } \\
\text { yield, \% }\end{array}$ & $\begin{array}{c}\text { Polyester } \\
\text { yield, \% }\end{array}$ & $\begin{array}{c}\text { CMC, } \\
\%\end{array}$ & $\begin{array}{c}\text { Maximum reduction of } \\
\text { surface tension, Mn/m }\end{array}$ \\
\cline { 2 - 9 }$n n n$ \\
\hline 1 & DEP-4 & 10 & 9 & 22 & $97-99.6$ & $95-97$ & 0.033 & 39 \\
\hline 3 & DEP-6 & 10 & 9 & 22 & $97-99.7$ & $96-98$ & 0.028 & 41 \\
\hline
\end{tabular}


Table 2 shows the DCU yields, these values allow controlling the completeness of the reaction and the yield of the resulting polyester after its separation from the reaction mixture. In Table 2 samples 1 and 2 are polyphosphoesters obtained using the corresponding modified macromolecules of polyethylene glycol (DEP). Sample 3 is PPAA obtained under similar conditions using unmodified polyethylene glycol. It can be concluded that the introduction of the ethyl phosphate group in the structure of polyethylene glycol does not significantly affect the yield of DCU and polyester. One can assume that this modification does not significantly affect the peculiarities of the Steglich reaction. This assumption is confirmed by the NMR spectra. Fig. 2 shows the NMR spectrum of PPE with the scheme of its signals (Fig. 2a) in comparison with the corresponding spectrum of PPAA obtained with unmodified PEG (Fig. $2 b)$. The assignment of signals and the ratio of their intensities fully confirm the expected structure of polyesters. Fig $2 \mathrm{a}$ in comparison with Fig. $2 \mathrm{~b}$ shows the expected signal complication in the range of $3.8-4.8 \mathrm{ppm}$ due to methylidene groups in the $\alpha$-position to the phosphorus group ( $\mathrm{G}$ protons) with a corresponding change in the ratio of their intensity and the relative increase in signal intensity. Also, the signal intensity of the ethyl group in the ethyl phosphate group (L) changes, in the range of $3.4-3.8 \mathrm{ppm}$, and a corresponding change in signal intensity in the range of $1.2-1.4$ ppm takes place - methyl protons of the above-mentioned ethyl group (M) are observed on the background of methylidene group protons of the alkyl fragment.

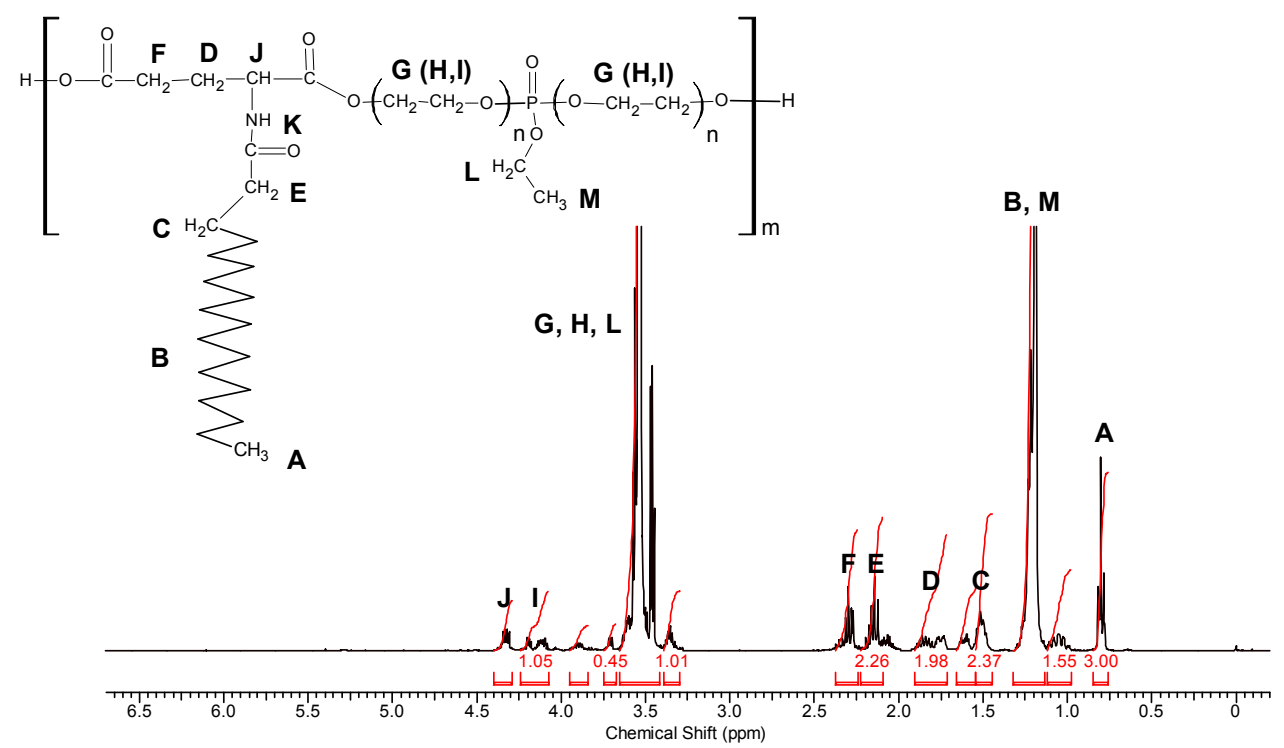

a)

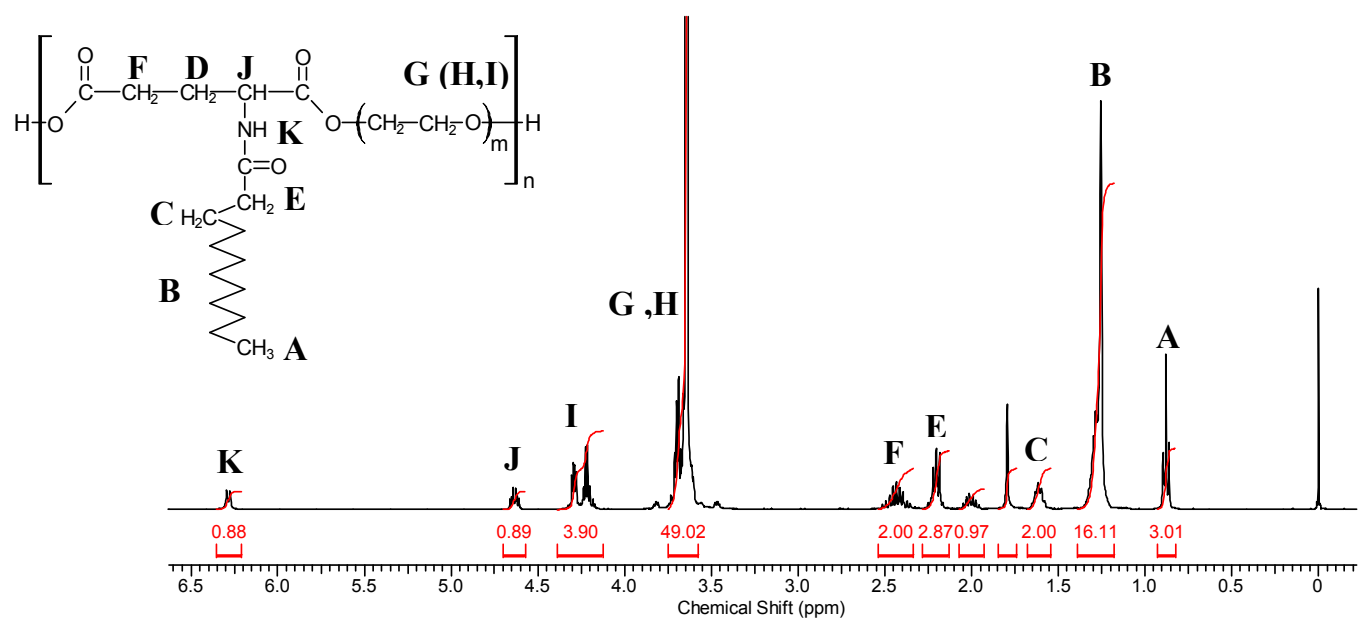

b)

Fig. 2. ${ }^{1} \mathrm{H}$ NMR spectra of PPE based on GluSt and DEP-4 with ethyl phosphate group (a); PPAA based on GluL and PEG-600 (b) 


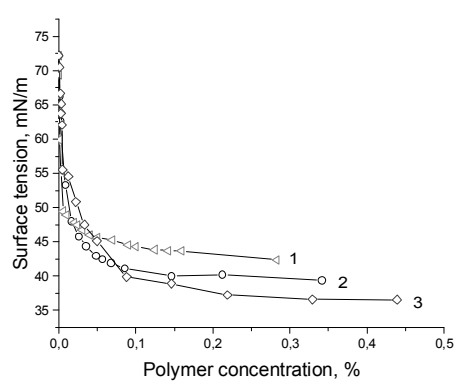

Fig. 3. Surface tension isotherms of PPAA (GluSt/PEG400) (1); PPE (GluSt/DEP-4) with ethyl phosphate group (2) and PPE (GluSt/DEP-4) with phosphate group (after hydrolysis) (3)

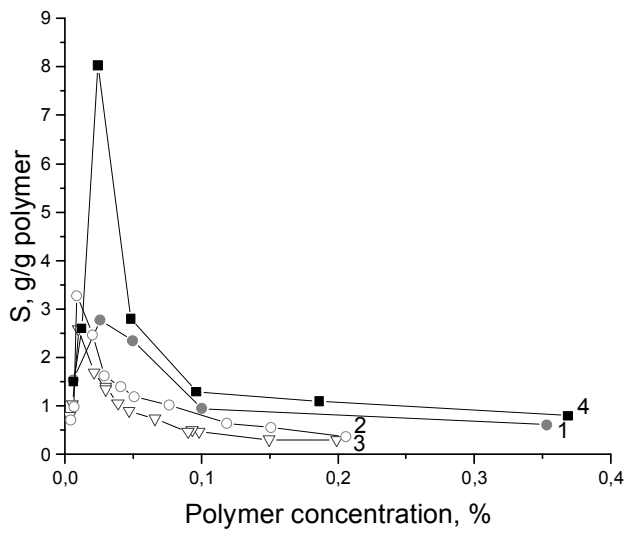

Fig. 5. Solubilization capacity of PPE (GluSt/DEP-4) with ethyl phosphate group (1); PPAA (GluSt/PEG400) (2); PPAA (GluSt/PEG600) (3) and PPE (GluSt/DEP-4) with phosphate group (after hydrolysis) (4)

As was mentioned in the introduction, to be suitable for drug delivery systems, polymers should possess surfaceactive properties. It is shown, pseudo-poly(amino acid)s of polyester type obtained based on N-stearoyl glutamic acid and polyethylene glycols have these properties. Moreover, studies of the obtained PPE revealed that the introduction of ethylphosphate group into the polyoxyethylene fragment to some extent affects surface-active properties, but PPEs are still surface-active. Fig. 3 shows the surface tension curves of PPE obtained using DEP of different molecular weights in comparison with PPAA of the similar structure obtained using unmodified PEG.

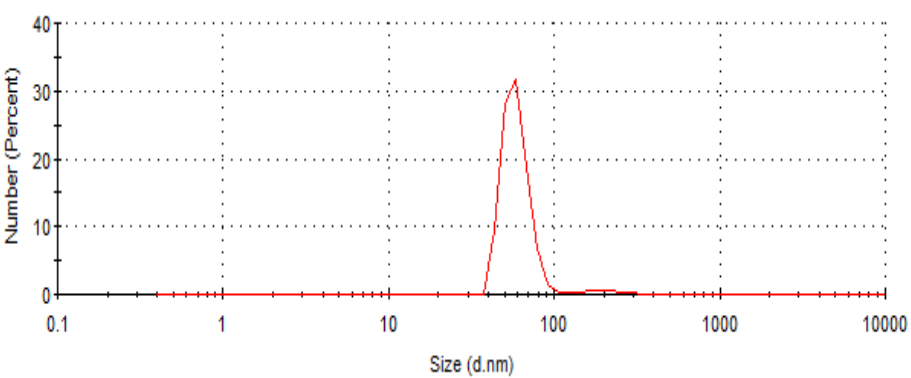

Fig. 4. Size distribution curve of the PPE (GluSt/DEP-4) with a phosphate group (after hydrolysis)

These curves confirm that the synthesized PPE have similar surfactant properties; the values of this activity given in Table 2 show that PPEs are even more surfaceactive compared to PPAA with a similar structure. Accordingly, PPEs have the ability to form self-stabilized dispersions with a nanometric dispersed phase in aqueous media. This confirms the particle size distribution of the dispersed phase obtained by the dynamic light scattering method (Fig. 4).

Fig. 5 shows the dependence of the solubilization capacity of the obtained PPE in comparison with the corresponding analogs of PPAA. It should be noted that with approximately the same solubilization capacity of phosphorus-containing polyesters PPEs (curve 1) in comparison with non-phosphorus-containing analogs PPAAs, PPEs have a wider range of concentrations where high solubilization capacity is maintained (curves 2 and 3). There is a rapid increase in solubilization capacity (curve 4) after hydrolysis of the ethyl phosphate group to the phosphate group under mild conditions. Thus, one can argue that the introduction of the phosphate group into the structure of the polyoxyethylene fragment leads to an increase in the absorption and solubilization properties of aqueous dispersions.

The cytotoxicity of the obtained PPE was studied using their effect on the survival of bull sperm and the activity of oxidative enzymes (Table 3 ). The introduction of polyesters into the nutrient medium in doses of $100 \mu \mathrm{g} / \mathrm{ml}$ does not reduce cell survival. It indicates the absence of cytotoxic effect of the resulting polyester. This conclusion is confirmed by additional studies - these doses of polyester also do not reduce the activity of oxidative processes.

Table 3. Sperm survival and the activity of their oxidative enzymes under the action of PPE (GluSt/DEP-4) with phosphate group (after hydrolysis) $(\mathrm{n}=8, \mathrm{M} \pm \mathrm{m}$ )

\begin{tabular}{|c|c|c|c|}
\hline \multirow{2}{*}{ Dosage, $\mu \mathrm{g} / \mathrm{ml}$} & \multirow{2}{*}{ Survival, $\mathrm{h}$} & Enccinate dehydrogenase (SDH) & Cytochrome oxidase $(\mathrm{CHO})$ \\
\cline { 3 - 4 } & $54.0 \pm 7.04$ & $11.8 \pm 2.69$ & $18.3 \pm 2.55$ \\
\hline 100 & $51.0 \pm 5.09$ & $14.2 \pm 2.48$ & $17.5 \pm 1.95$ \\
\hline 50 & $60.0 \pm 8.49$ & $15.8 \pm 3.98$ & $14.2 \pm 2.74$ \\
\hline 10 & 0.148 & 0.256 & 0.301 \\
\hline Correlation, $\eta$ & $54.0 \pm 9.25$ & $17.5 \pm 3.49$ & $14.2 \pm 2.48$ \\
\hline Control & & & \\
\hline
\end{tabular}




\section{Conclusions}

This report presents the experimental material on a convenient synthetic approach to a new class of polyester by irreversible polycondensation of $\mathrm{N}$-alkyl derivatives of dicarboxylic $\alpha$-amino acids with polyoxyethylene glycols containing phosphates in their structures. Synthetically convenient polycondensation techniques can be constructed by the Steglich reaction mechanism. Obtained poly(phosphoester)s form self-stabilized aqueous dispersions with nanometric dispersed phase. Studies show that aqueous dispersions of the obtained polymers are able to solubilize significant amounts of waterinsoluble organic compounds and are non-toxic. Based on the described experimental data, it can be concluded that the developed method of polyphosphoesters and a set of properties make them promising for use as polymer disperse delivery systems for therapeutic agents.

\section{References}

[1] Brannigan, R.P.; Dove, A.P. Synthesis, Properties and Biomedical Applications of Hydrolytically Degradable Materials Based on Aliphatic Polyesters and Polycarbonates. Biomater. Sci. 2017, 5, 9-21. https://doi.org/10.1039/c6bm00584e [2] Urbánek, T.; Jäger. E.; Jäger, A.; Hrubý, M. Selectively Biodegradable Polyesters: Nature-Inspired Construction Materials for Future Biomedical Applications. Polymers 2019, 11, 1061. https://doi.org/10.3390/polym11061061

[3] Brzozowski, Z.K.; Szymańska, E.; Bratychak, M.M. New Epoxy-Unsaturated Polyester Resin Copolymers. React. Funct. Polym. 1999, 33, 217-224. https://doi.org/10.1016/s13815148(97)00045-x

[4] Manavitehrani, I.; Fathi, A.; Badr, H.; Daly, S.; Shirazi, A.N.; Dehghani, F. Biomedical Applications of Biodegradable Polyesters. Polymers 2016, 8, 20. https://doi.org/10.3390/polym8010020

[5] Varvarenko, S.; Tarnavchyk, I.; Voronov, A.; Fihurka, N.; Dron, I.; Nosova, N.; Taras, R.; Samaryk, V.; Voronov, S. Synthesis and Colloidal Properties of Polyesters Based on Glutamic Acids and Glycols of Different Nature. Chem. Chem. Technol. 2013, 7, 161168. https://doi.org/10.23939/chcht07.02.161

[6] Bashta, B.; Bruzdziak, P.; Astakhova, O.; Shyshchak, O.; Bratychak, M. Synthesis and Properties of Carboxy-Containing Peroxy Oligomer. Chem. Chem. Technol. 2013, 7, 413-421. https://doi.org/10.23939/chcht07.04.413

[7] Ratner, B.D.; Hoffman, A.S.; Schoen, F.J.; Lemons, J.E. Introduction-Biomaterials Science: An Evolving, Multidisciplinary Endeavor. In Biomaterials Science, 3rd ed.; Lemons, B.D., Ratner, A.S., Hoffman, F.J., Schoen, J.E., Eds.; Academic Press: Boston, MA, USA, 2013; pp 25-39. https://doi.org/10.1016/B978-0-08087780-8.00153-4

[8] Diaz, A.; Katsarava, R.; Puiggali, J. Synthesis, Properties and Applications of Biodegradable Polymers Derived From Diols and Dicarboxylic Acids: From Polyesters to Poly(Ester Amide)s. Int. $J$ Mol. Sci. 2014, 15, 7064-7123.

https://doi.org/10.3390/ijms15057064

[9] Yakoviv, M.; Fihurka, N.; Nosova, N.; Samaryk, V.;

Vasylyshyn, T.; Hermanovych, S.; Voronov, S.; Varvarenko, S.
Researches of Amphiphilic Properties of Copolyesterswith

Chromophore Groups. Chem. Chem. Technol. 2018, 12, 318-325.

https://doi.org/10.23939/chcht12.03.318

[10] Bratychak, M.; Bratychak, M.; Brostow, W.; Shyshchak, O. Synthesis and Properties of Peroxy Derivatives of Epoxy Resins

Based on Bisphenol A: Effects of the Presence of Boron Trifluoride Ethereate. Mater. Res. Innov. 2002, 6, 24-30.

https://doi.org/10.1007/s10019-002-0157-7

[11] Da Costa, R.C.; Pereira, E.D.; Silva, F.M.; De Jesus, E.O.; Souza Jr., F.G. Drug Micro-Carriers Based on Polymers and Their Sterilization. Chem. Chem. Technol. 2018, 12, 473-487.

https://doi.org/10.23939/chcht12.04.473

[12] Ivashkiv, O.; Namiesnik, J.; Shyshchak, O.; Polyuzhyn, I.;

Bratychak, M. Synthesis and Properties of Oligomers with Hydroxy End-Groups. Chem. Chem. Technol. 2016, 10, 587-594.

https://doi.org/10.23939/chcht10.04si.587

[13] Ivanchenko, O.; Authesserre, U.; Coste, G.; Mazières, S.; Destarac, M.; Harrisson, S. E-Thionocaprolactone: An Accessible Monomer for Preparation of Degradable Poly(Vinyl Esters) by Radical Ring-Opening Polymerization. Polym. Chem. 2021, 12, 1931-1938. https://doi.org/10.1039/D1PY00080B

[14] Wang, Y.-C.; Yuan, Y.-Y.; Du, J.-Z.; Yang, X.-Z.; Wang, J. Recent Progress in Polyphosphoesters: From Controlled Synthesis to Biomedical Applications. Macromol. Biosci. 2009, 9, 1154-1164. https://doi.org/10.1002/mabi.200900253

[15] Buls, V.W.; Creek, W.; Morris, R.C. Polyesters of PhosphorylSubstitute Alcohols and Polybasic Phosphorus Acids. U.S. Patent 2807636, September 24, 1957.

[16] Yang, X.-Z.; Sun, T.-M.; Dou, S.; Wu, J.; Wang, Y.-C.; Wang, J. Block Copolymer of Polyphosphoester and Poly(1-Lactic Acid) Modified Surface for Enhancing Osteoblast Adhesion, Proliferation, and Function. Biomacromolecules 2009, 10, 2213-2220.

https://doi.org/10.1021/bm900390k

[17] Strasser, P.; Teasdale, I. Main-Chain Phosphorus-Containing Polymers for Therapeutic Applications. Molecules 2020, 25, 1716. https://doi.org/10.3390/molecules25071716

[18] Vanslambrouck, S.; Riva, R.; Ucakar, B.; Préat, V.; Gagliardi, M.; Molin, D.G.M.; Lecomte, P.; Jérôme, C. Thiol-ene Reaction:

An Efficient Toolto Design Lipophilic Polyphosphoesters for Drug Delivery Systems. Molecules 2021, 26, 1750.

https://doi.org/10.3390/molecules26061750

[19] Bauer, K.N.; Tee, H.T.; Velencoso, M.M.; Wurm, F.R. MainChain Poly(Phosphoester)s: History, Syntheses, Degradation, Bioand Flame-Retardant Applications. Prog. Polym. Sci. 2017, 73, 61122. https://doi.org/10.1016/j.progpolymsci.2017.05.004

[20] Steinbach, T.; Wurm, F.R. Poly(Phosphoester)s: a New Platform For Degradable Polymers. Angew. Chem. Int. Ed. 2015, 54, 6098-6108. https://doi.org/10.1002/anie.201500147

[21] Schöttler, S.; Becker, G.; Winzen, S.; Steinbach, T.; Mohr, K.; Landfester, K.; Mailänder, V.; Wurm, F.R. Protein Adsorption is Required for Stealth Effect of Poly(Ethylene Glycol)- and Poly(Phosphoester)-Coated Nanocarriers. Nat. Nanotechnol. 2016, 11,372-377. https://doi.org/10.1038/nnano.2015.330

[22] Pelosi, C.; Tinè, M. R.; Wurm, F.R. Main-Chain Water-Soluble Polyphosphoesters: Multi-Functional Polymers as Degradable PEGAlternatives for Biomedical Applications. Eur. Polym. J. 2020, 141, 110079. https://doi.org/10.1016/j.eurpolymj.2020.110079

[23] Nicolas, J.; Mura, S.; Brambilla, D.; Mackiewicz, N.;

Couvreur, P. Design, Functionalization Strategies and Biomedical Applications of Targeted Biodegradable/Biocompatible PolymerBased Nanocarriers for Drug Delivery. Chem. Soc. Rev. 2013, 42, 1147-235. https://doi.org/10.1039/C2CS35265F

[24] Gordillo-Galeano, A.; Ponce, A.; Mora-Huertas, C.E. Surface Structural Characteristics of Some Colloidal Lipid Systems Used in 
Pharmaceutics. J. Drug Deliv. Sci. Technol. 2021, 62, 02345. https://doi.org/10.1016/j.jddst.2021.102345

[25] Idrees, H.; Zaidi, S.Z.J.; Sabir, A.; Khan, R.U.; Zhang, X.; Hassan, S-U. A Review of Biodegradable Natural Polymer-Based Nanoparticles for Drug Delivery Applications. Nanomaterials 2020, 10, 1970. https://doi.org/10.3390/nano10101970

[26] Atanase, L.I. Micellar Drug Delivery Systems Based on Natural Biopolymers. Polymers 2021, 13, 477.

https://doi.org/10.3390/polym13030477

[27] Varvarenko, S.M.; Ferens, M.V.; Samaryk, V.Y.; Nosova, N.G.; Fihurka, N.V.; Ostapiv, D.D.; Voronov, S.A. Synthesis of Copolyesters of Fluorescein and 2-(Dodecanamino) Pentanedionic Acid via Steglich Reaction. Voprosy Khimii i Khimicheskoi Tekhnologii 2018, 2, 5-15.

[28] Kuznetsova, K.I.; Vostres, V.B.; Fleychuk, R.I.; Hevus, O.I. Synthesis of Surface-Active Monomers and Peroxides on the Basis of Disubstituted Oxetane. Voprosy Khimii i Khimicheskoi Tekhnol. 2019, 2, 5-11. https://doi.org/10.32434/0321-4095-2019-123-2-5-11 [29] Nagornyak, M.; Fihurka, N.; Samaryk, V.; Varvarenko, S.; Ferens, M.; Oleksa, V. Modification of Polysaccharides By NDerivatives of Glutamic Acid Using Steglich Reaction. Chem. Chem. Technol. 2016, 10, 423-427.

https://doi.org/10.23939/chcht10.04.423

[30] Zubyk, H.; Plonska-Brzezinska, M.; Shyshchak, O.; Astakhova, O.; Bratychak, M. Study of Phenol-Formaldehyde Oligomers Derivatives Structure by IR- and NMR-Spectroscopy. Chem. Chem. Technol. 2015, 9, 435-444.

https://doi.org/10.23939/chcht09.04.435

[31] Ivashkiv, O.; Astakhova, O.; Shyshchak, O.; PlonskaBrzezinska, M.; Bratychak, M. Structure and Application of ED-20 Epoxy Resin Hydroxy-Containing Derivatives in BitumenPolymeric Blends. Chem. Chem. Technol., 2015, 9, 69-76. https://doi.org/10.23939/chcht09.01.069

[32] Iatsyshyn, O.; Astakhova, O.; Shyshchak, O.; Lazorko, O.; Bratychak, M. Monomethacrylate Derivative of Ed-24 Epoxy Resin and Its Application. Chem. Chem. Technol., 2015, 7(1), 73-77. https://doi.org/10.23939/chcht07.01.073

[33] Demchuk, Z.; Savka, M.; Voronov, A.; Budishevska, O.; Donchak, V.; Voronov, S. Amphiphilic Cholesterol Containing
Polymers for Drug Delivery Systems. Chem. Chem. Technol. 2016, 10, 561-570. https://doi.org/10.23939/chcht10.04si.561

[34] Matysik, S. I.; Kuzminov, B. P.; Ostapiv, D. D. Cytotoxic Action of Hepatoprotector Antral on Bull Sperm. Gig. Sanit. 2020, 99, 206209. https://doi.org/10.33029/0016-9900-2020-99-2-206-209

[35] Chekh, B.O.; Ferens, M.V.; Ostapiv, D.D.; Samaryk, V.Y.; Varvarenko, S.M.; Vlizlo, V.V. Characteristics of Novel Polymer Based on Pseudo-Polyamino Acids Glula-DPG-PEG600: Binding of Albumin, Biocompatibility, Biodistribution and Potential Crossing the Blood-Brain Barrier in Rats. Ukr. Biochem. J. 2017, 89, 13-21. https://doi.org/10.15407/ubj89.04.013

[36] Fihurka, N.; Tarnavchyk, I.; Samaryk, V.; Varvarenko, S.; Nosova, N.; Voronov, A.; Nagornyak, M.; Ferens, M.; Voronov, S.A. Study of an Irreversible Condensation of Glutamic Acid and Polyoxyethylene/Polyoxypropylene Diols Using Thionyl Chloride. Org. Prep. Proc. Int. 2018, 50, 502-508.

https://doi.org/10.1080/00304948.2018.1525674

Received: June 15, 2021 / Revised: July 02, 2021 / Accepted: September 01, 2021

\section{СИНТЕЗ ТА ВЛАСТИВОСТІ ФОСФОРОВМІСНИХ ПСЕВДОПОЛІАМІНОКИСЛОТ ПОЛІЕСТЕРНОГО ТИПУ НА ОСНОВІ N-ПОХІДНИХ ГЛУТАМІНОВОї КИСЛОТИ}

Анотація. Поліфосфоестери (ПФЕ) - ие клас полімерів, щзо володіють високою хімічною функиіональністю та здатністю до біологічного розкладання. Синтезовані нові поліфосфоестери на основі глутамінової кислоти за реакиією Стегліха. Розроблений синтетичний підхід дозволяє контролювати склад $і$ структуру ПФЕ, а отже, їх фізичні та колоїдні властивості. Дослідження солюбілізації та цитотоксичності in vitro довели потенціал застосування ПФЕ для доставки лікарських препаратів.

Ключові слова: поліфосфоестери, псевдополіамінокислоти, глутамінова кислота, поліетиленгліколь, реакиія Стегліха, доставка ліків. 